\title{
A kórházi adatlapok jelentéseinek alkalmazhatósága epidemiológiai elemzésekre az ischaemiás cerebrovascularis betegségek példája alapján
}

\author{
Ajtay András dr. ${ }^{1}$ - Oberfrank Ferenc dr. ${ }^{2}$ - Bereczki Dániel dr. ${ }^{1}$ \\ 'Semmelweis Egyetem, Általános Orvostudományi Kar, Neurológiai Klinika, Budapest \\ ${ }^{2}$ Magyar Tudományos Akadémia Kísérleti Orvostudományi Kutatóintézete, Budapest
}

\begin{abstract}
Bevezetés: Egybiztosítós egészségügyi finanszírozási rendszerben a kórházak által finanszírozási célból történő adatszolgáltatások lehetőséget adhatnak epidemiológiai jellegű vizsgálatokra. Célkitüzés: A szerzők Közép-Magyarország 14 neurológiai osztálya adatai alapján vizsgálták a jelentések megbízhatóságát. Módszer: Az elemzést az agyi infarktus (BNO-10 I63+I64) három számjegyú diagnóziskódjaira végezték az Országos Egészségbiztosítási Pénztár számára küldött kórházi jelentésekből kiindulva. Eredmények: Az ischaemiás cerebrovascularis esetek száma 2012 első és második fél évét összehasonlítva 35\%-os csökkenés és 73\%-os növekedés között változott: az egyes kórházakban jól követte az ellátási területek 2012. júliusi változását. Kiegészítő informatikai módszerekkel megbecsülhető, hogy az agyinfarktus kórháztól függően az esetek 54-84\%-ában akut esemény. A neurológiai osztályok szerepvállalása az ischaemiás cerebrovascularis betegek ellátásában kórházanként 34-98\% között változik. A jelentésekben szereplő diagnózisok összességében több mint 99\%-ban megfelelnek a betegek zárójelentésében szereplő diagnózisoknak. Nagyobb pontatlanságok (körülbelül 20\%) a finanszírozási besorolási kódolásokban voltak. Következtetések: A finanszírozási célból létrehozott adatbázisok megfelelő informatikai módszerek alkalmazásával megbízható adatokat szolgáltatnak a magyarországi cerebrovascularis betegségek epidemiológiai vizsgálatára. Orv. Hetil., 2015, 156(38), $1540-1546$.
\end{abstract}

Kulcsszavak: BNO-10, stroke, adminisztratív adatbázis, megbízhatóság, területi elemzés

\section{Applicability of hospital reports submitted for reimbursement purposes for epidemiological studies based on the example of ischemic cerebrovascular diseases}

\begin{abstract}
Introduction: In single-payer health care financing systems data extracted from hospital report forms submitted for reimbursement purposes may be used for epidemiological investigations. Aim: Based on data submitted by 14 neurological wards in Central Hungary the authors examined the reliability of these reports. Method: Analyses were performed for the 3-digit codes of the 10th version of the International Classification of Diseases for cerebral infarcts (ICD-10 I63+I64) reported for the National Health Insurance Fund. Results: The number of cases in individual hospitals changed between a decrease by $35 \%$ and an increase by $73 \%$ from the first to the second half of the year 2012 , reflecting changes in the size of the catchment area of the hospitals in July 2012. Of those with an ICD-10 I63 or I64 discharge diagnosis $54-84 \%$ had acute stroke. Neurological wards cared for $34-98 \%$ of all stroke patients. The diagnoses submitted for reimbursement purposes corresponded in over $99 \%$ to the diagnoses in the hospital discharge reports. Inaccuracies occurred in a larger proportion (about 20\%) in coding the DRG financing categories. Conclusions: Databases created from hospital reports submitted for reimbursement purposes can be used reliably in Hungary for stroke epidemiological studies.
\end{abstract}

Keywords: ICD-10, stroke, administrative database, reliability, regional analysis 
Ajtay, A., Oberfrank, F., Bereczki, D. [Applicability of hospital reports submitted for reimbursement purposes for epidemiological studies based on the example of ischemic cerebrovascular diseases]. Orv. Hetil., 2015, 156(38), $1540-1546$.

(Beérkezett: 2015. július 8.; elfogadva: 2015. július 30.)

\section{Rövidítések}

BNO = Betegségek Nemzetközi Osztályozása; ESKI TEA = Egészségügyi Stratégiai Kutató Intézet Tételes Egészségügyi Adattára; HBCs = Homogén Betegségcsoportok; OEP = Országos Egészségbiztosítási Pénztár

Az idegrendszer betegségei a várható életkor növekedésével egyre nagyobb súllyal szerepelnek a morbiditási és mortalitási statisztikákban. A neurológiai betegségek társadalmi terhe napjainkban is jelentős: 2009-ben aktív neurológiai fekvőbeteg-ellátásban 103 ezer, neurológiai járóbeteg-ellátásban 1365 ezer, neurorehabilitációs osztályokon több mint 10 ezer esetet kezeltek a magyar állami egészségügyi ellátásban [1], tehát mindössze egyetlen év során - 1,2-1,4 közötti visszatérési aránnyal számolva - minden tizedik magyar állampolgár igénybe vett neurológiai betegellátást. Az idegrendszeri betegségek súlya még nagyobb: neurológiai kórképekben szenvedő betegeket ugyanis egyéb szakterületek is ellátnak. A stroke-kezelések például 2009-ben az esetek 61\%-ában neurológiai, 30\%-ában belgyógyászati, míg 9\%-ában valamely más szakterületen történtek [2].

Az epidemiológiai felmérések arany standardja a populációalapú vizsgálat, de az ilyen vizsgálatok nagyon költségesek, idő- és munkaerő-igényesek. Olyan egybiztosítós finanszírozási rendszerekben, ahol lényegében a teljes lakosság térítésmentesen jogosult az egészségügyi szolgáltatások igénybevételére, a szolgáltatók által finanszírozási céllal jelentett betegellátási adatok felhasználhatók lehetnek egyes kórképek epidemiológiai jellegzetességeinek vizsgálatára [3]. Az adatbázis megbízhatóságának igazolása fontos az ellátásszervezéshez és hatáselemzéshez is [4]. Nélkülözhetetlen a nagy adatbázis évekre visszamenőleges elemzési lehetősége, emellett az ilyen adatbázisok lehetőséget adnak nemzetközi öszszehasonlításokra is [5].

Az Országos Egészségbiztosítási Pénztár (OEP) számára készült jelentések kutathatósága a közelmúltban az Egészségügyi Stratégiai Kutató Intézet Tételes Egészségügyi Adattárának [6] felhasználásával lehetővé vált. Kérdéses lehet azonban az ilyen módon nyert adatok teljessége és megbízhatósága. Az orvosi jelentések finanszírozási szempontokat is tartalmazó adatbázisainak epidemiológiai kérdések megválaszolására való felhasználása előtt fontosnak tartottuk megvizsgálni az ilyen forrásból nyert adatok alkalmazhatóságát.
Az elemzéshez „modellbetegségként” az ischaemiás agyi vérkeringési zavart választottuk. Mivel 2012 nyarán a közép-magyarországi régióban megváltoztak a kórházak által ellátandó területek, a jelentések érzékenységének vizsgálatára fél éves bontásban elemeztük 2011 és 2012 adatait. Az egészségügyünk újkori történetében 2012-ben először került sor a kórházi felvételi területek hatósági meghatározására a korábbi konszenzusos megoldás helyett. 2012 előtt egy adott kórházi szakterületnek - így a neurológiának is - csak egy felvételi területe volt. A 2012. július 1-jétől hatályos hatósági meghatározásban akár négy különböző hatóságilag kitűzött ellátási területet is kaphatott egy-egy szakma a „progresszív ellátás” címszava alatt. Az időszaki összehasonlításokkal nemcsak demográfiai elemzéseket, hanem az intézkedés előtti év két fél éve és az intézkedés utáni év két fél éve osztályos betegforgalmának összehasonlításával elemezni tudtuk a hatósági intézkedés hatását is egy-egy szakmai osztályra. A neurológiai ellátáson belül speciális helyzetet jelent a stroke-ellátás, amely a neurológiák betegforgalmának átlagosan 53\%-át teszik ki. A 2012-es változások alkalmával a stroke-ellátási területeket a neurológia egyéb részeitől elkülönítve, függetlenül osztották el, így - elsősorban a fóvárosban - egy adott neurológiai osztályt más-más terület ellátására köteleztek a stroke ellátása és az egyéb neurológiai betegségek ellátása szempontjából.

A kórházi jelentések és az ESKI adatbázis egyezősége mellett vizsgáltuk a HBCs-kódolások (Homogén Betegségcsoportok rendszer) tartalmi megbízhatóságát is. Erre a 2005-ös OEP tételes ellenőrzési adatokat tekintettük át [7]. Az ellenőrzés során az ország területén 25 kórház 8043 cerebrovascularis eset dokumentációjának egyenkénti átvizsgálásával egyrészt azt ellenőrizték, hogy az osztályok által jelentett cerebrovascularis betegség HBCs-diagnózisait alátámasztják-e a kórrajzban szereplő dokumentumok, másrészt, hogy a kórházak által jelentett adatok megegyeznek-e az OEP-nél rögzített adatokkal.

\section{Módszer}

Az OEP-jelentések kutathatósága az egyes betegek személyes adatainak ismerete nélkül (anonimizáltan) lehetséges az ESKI TEA adatbázis [6] felhasználásával. Az elemzést az agyi infarktus (Betegségek Nemzetközi Osztályozása, BNO-10 I63+I64) három számjegyü diagnó- 
1. táblázat |A közép-magyarországi régió neurológiai osztályai

\begin{tabular}{lc}
\hline Neurológia & Ágyszám \\
\hline Semmelweis Egyetem & 115 \\
Dél-Pesti Kórház & 82 \\
Pest Megyei Flór Ferenc Kórház & 65 \\
Honvéd Kórház & 63 \\
OITI & 59 \\
& \\
Vác Városi Kórház & 55 \\
Szent János Kórház & 55 \\
Szent Imre Kórház & 48 \\
Cegléd Városi Kórház & 46 \\
Uzsoki úti Kórház & 45 \\
& \\
Szent István Kórház & 40 \\
Péterfy Sándor Kórház & 40 \\
Bajcsy-Zsilinszky Kórház & 40 \\
Nyírő Gyula Kórház & 35 \\
\hline
\end{tabular}

ziskódjaira végeztük el, mivel a háromjegyű BNO-diagnózisok statisztikai elemzésekre bizonyítottan alkalmasak.

Az országos adatokból kiemelt közép-magyarországi régiót kórházanként vizsgáltuk. A 2012. év agyi infarktusainak teljes kórházi és azon belül a neurológiai osztályos kezeléseit is elemeztük havi bontásban a kórház összes ágyán, és ezen belül az aktív, a krónikus és az egynapos ellátások (kúraszerú) ágyain is. Az ellátási területek 2012. júliusi változása miatt 2011 és 2012 két fél évének adatait is összehasonlítottuk. A közép-magyarországi régió 14 kórházában múködő neurológiai osztályoknak (1. táblázat) fél éves bontásban megküldtük a 2011-re és 2012-re vonatkozó esetszámokat, visszajelzést kérve, hogy a BNO-10-diagnózisok szerinti ESKI-esetszámok egyeznek-e a kórházak által jelentett kórházi esetszámokkal. Az ábrákon az egyes kórházakat anonimizáltan szerepeltetjük.

A finanszírozási célból leadott adatlapok megbízhatóságát a 2005-ös OEP-ellenőrzés összefoglaló jegyzőkönyve [7] alapján vizsgáltuk meg, amely egyenként vetette össze 8043 kifizetett adatlap és a hozzájuk tartozó zárójelentések tartalmát. Az elemzés 25 fekvőbeteg-ellátó intézet 8043 cerebrovascularis esetére terjedt ki. A vizsgált diagnózisok a BNO-10 verzió I60-I69 diagnózisai voltak. Az elemzés során a megyei egészségbiztosítási pénztárak fóorvosai egyrészt ellenőrizték a jelentett adatlap és a zárójelentés diagnózisainak tartalmi azonosságát (hitelességét), másrészt ellenőrizték, hogy a zárójelentés diagnózisainak orvos által kódolt diagnózistípus-meghatározása (alapbetegség, szövődmény, kísérő betegség) a HBCs-besoroláshoz megfelelő volt-e. A HBCs-besorolás finanszírozási előnyt adhat. Míg az or- vosi dokumentációban nem szereplő diagnózisok adatlapi megjelenítése hitelességi körbe sorolandó, tehát a kifizetett összeg büntető visszavonását jelenti, addig a diagnózistípusok besorolásával - tehát létező diagnózisoknál - elért előnyök csak újrabesorolással és a pluszöszszeg visszavonásával jártak. Jelen munkánkban az idézett ellenőrzés következtetéseit összegző jegyzőkönyv tartalmát vettük figyelembe.

\section{Eredmények}

\section{A közép-magyarországi régió részletes elemzése}

A közép-magyarországi régió 14 kórházában múködő 788 neurológiai ágy az országban lévő neurológiai ágyak 29\%-a. Az ágyszám megfelel az ország és a régió lakosságszámarányának. Vizsgáltuk az agyinfarktusnak minősített esetszámokat, és 2012 első és második fél évét összehasonlítva felmértük, hogy a területi ellátási kötelezettségek változása tükröződik-e az osztályok forgalmában. Elemeztük továbbá az agyinfarktusok arányát az egyes neurológiai osztályok betegforgalmában, vizsgáltuk az agyinfarktusnak jelentett esetek között azok arányát, akiknél az agyinfarktus volt az ápolás fó indoka, végül a neurológiai osztályok kórházon belüli súlyát mértük fel az agyinfarktus miatt kezelt betegek ellátásában.

A közép-magyarországi régióban a kórházak aktív ágyain az ellátási terület 2012-es hatósági átrendezése miatt bekövetkezett változásokat vázoljuk fel az 1 . ábrán. Látható, hogy három neurológiai osztályon jelentősen megnőtt a felvett agyi infarktusok száma az év második felében: ezen osztályok stroke-ellátási kötelezettségi területe 2012 júliusától megnőtt. A legnagyobb növekedés 73\% volt. Azon kórházakban, ahol csökkentek az ellátandó területek, csökkent az agyi infarktusok miatt ellátottak száma is. A legnagyobb mértékű csökkenés a Semmelweis Egyetemet érintette $(-35 \%)$, ahol az első progresszivitási szintű neurológiai ellátási terület a fóvá-

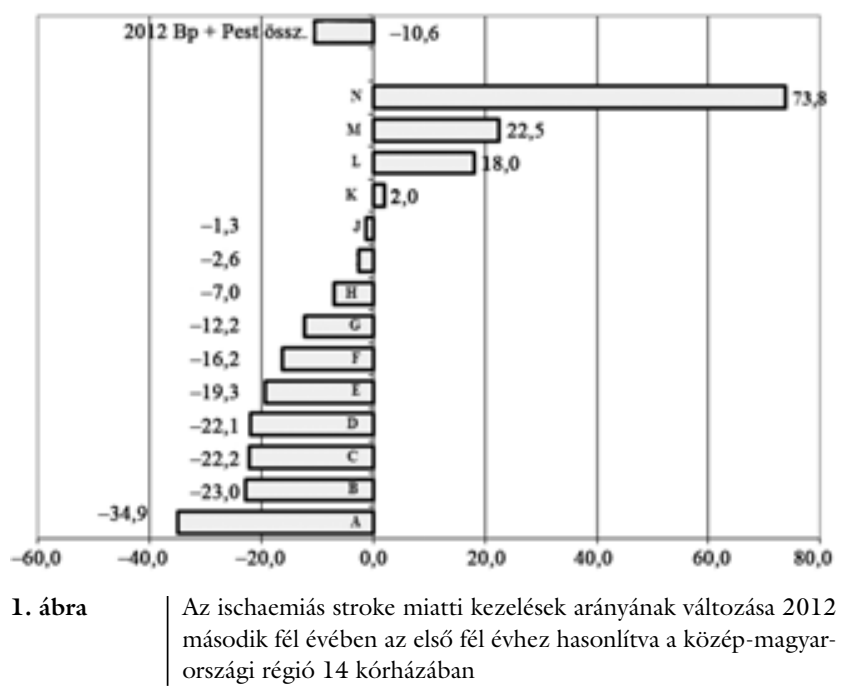




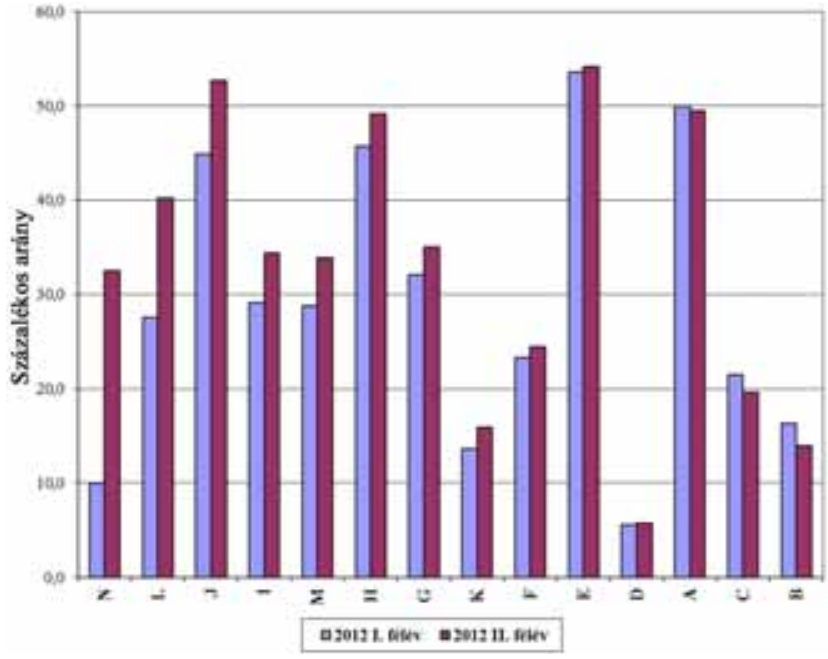

2. ábra

A stroke - mint ápolást indokoló fó diagnózis - aránya a 14 neurológiai osztályról elbocsátott összes beteghez képest 2012 első és második fél évében a két fél év forgalmának különbsége sorrendjében

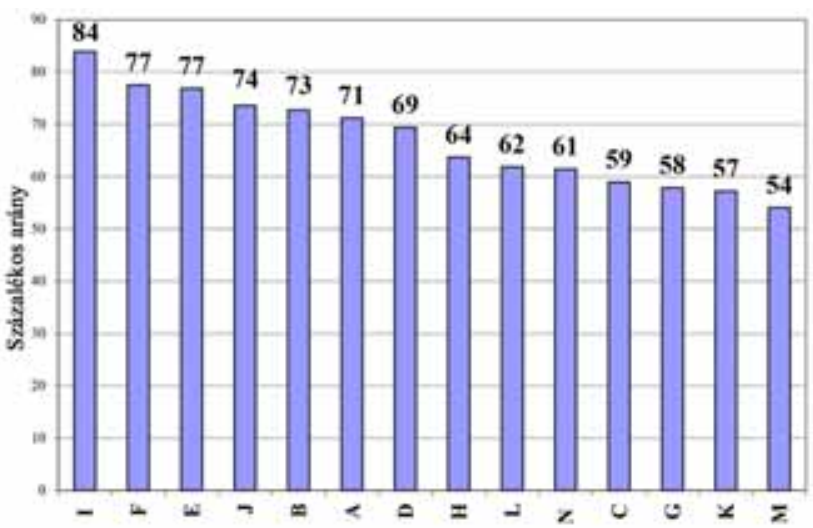

3. ábra

A vizsgált 14 kórházban az agyi infarktus diagnózisokon belül az infarktus - mint ápolást indokoló fó diagnózis - aránya. Az agyinfarktus ápolást indokoló fó diagnózisként az összes agyinfarktus 54-84\%-ában jelenik meg, tehát az agyinfarktus kórháztól függően az esetek 16-46\%-ában mellékdiagnózisként szerepel az OEP-jelentésekben roson kívüli (Pest megyei), a stroke-ellátási terület ezzel szemben pedig fővárosi: az ellátandó két terület nem is határos egymással. A 2. ábrán 2012 első és második fél évére bontva mutatjuk be a régió kórházaiban az agyinfarktusok arányát az osztályokról elbocsátott betegek számához viszonyítva. Három osztályon jelentôsen megnőtt az elbocsátott betegek között az agyinfarktusok aránya. Az ellátási teriuletek változásából evedö diagnózisspecifikus forgalmi adatok változása az ESKI TEA adatbázis elemzésével tehát jól érzékelhetō.

Külön kérdeztük le azokat a betegeket, akiknek felvételét és kezelését a jelentés szerint az agyi infarktus indokolta, azaz a stroke-ot az ápolást indokoló fó diagnózisként jelölték az adatlapon és azokat, akiknek diagnózisai között az agyi infarktus kísérő betegségként szerepelt. A 3. ábrán a bármilyen ellátásra (egynapos ellátás, aktív vagy krónikus ágy) felvett betegek szerepelnek. A grafikonon az látszik, hogy milyen arányban volt az agyinfarktus az ápolást indokoló diagnózis. Az adatbázisból közvetlenül nem derül ki, hogy az agyi infarktus felvételére az akut esemény miatt került sor vagy utókezelés miatt vették fel. Feltételezhetjük azonban, hogy akiknél az agyinfarktus kísérő betegségként szerepel, ott a felvétel oka nem akut stroke lehetett, hanem az agyinfarktus melléklelet volt. Ha a kódolás megfelelö, akkor az OEPadatbázis tehát alkalmas a valóban stroke miatt felvett betegek elkülönitésére azoktól, akiket más betegség miatt vettek fel, és akiknél az agyinfarktus mellékleletként derïlt ki a kezelés során.

Az adatbázis lekérdezése során lehetőség nyílik a diagnózisok és az ellátó osztályok szakmakódjának összekapcsolására. A 4. ábrán látható, hogy a 14 kórházból kilencben a neurológiai osztály látja el az agyi infarktusok döntő többségét (>80\%-át). Három neurológiai osztály az országos átlagnak (50-60\%) megfelelő arányban veszi ki részét az agyi infarktusok ellátásában. Két kórház esetében viszont a stroke miatt felvett esetek többségét nem neurológiai osztályon látják el. A 2. ábra adataiból megítélhető, hogy a stroke-ellátásban ezen két osztálynál tapasztalható kis arány hátterében nem a 2012. évi új területi elosztás áll, azaz nem a területi ellátás változása okozta a neurológiai osztály alacsony kórházon belüli részvételét a stroke-ellátásban. A 2 ábrán látható, hogy a területi ellátási kötelezettség változása után néhány kórházban ugyan jelentősen megnőtt az agyinfarktusos betegek aránya a neurológiai osztályok betegforgalmában 2012 második fél évében az előző fél évhez hasonlítva, de számottevő csökkenés egyetlen osztályon sem fordult elő. $A z$ adatbázis lekérdezése tehát alkalmas annak elemzésére, hogy az egyes neurológiai betegségeket milyen arányban látják el nem neurológiai szakterületeken.

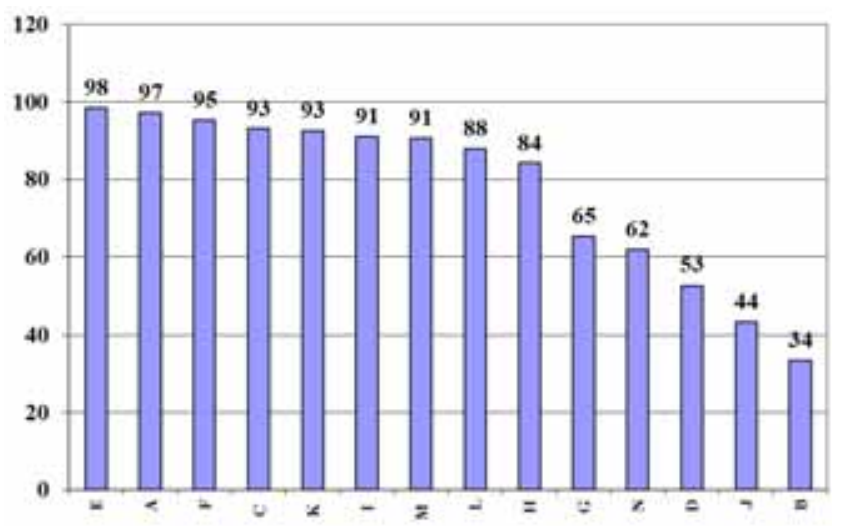

4. ábra $\quad$ A 14 neurológiai osztály részvétele a kórházon belül a stroke fó indokkal felvett betegek ellátásában 


\section{A 2005. évi országos ellenörzés adatainak áttekintése}

Az országos ellenőrzés az OEP-nél szereplő elektronikus adatok és a kórrajzokban szereplő adatlapok, zárójelentések között gyakorlatilag teljes megfelelőséget talált: hiányzó vagy nem elfogadható (nem hiteles) adatlapot mindössze 0,3\%-ban találtak. Az OEP-nél nyilvántartott jelentések tehát több mint 99,5\%-ban megfelelnek a betegek zárójelentésében szereplő diagnózisoknak. A nagyobb eltérések a finanszírozási besorolási kódolásokban voltak. Ebből a szempontból az ellenőrzés során a 25 kórház átlagában az esetek 20,1\%-ában találtak hibát vagy hiányosságot a fő diagnózis (1-2. kód), a szövődmények (4. kód) vagy a kísérő betegségek (5. kód) finanszírozási típus besorolásában. A dokumentációban nem szereplő diagnózisra utaló kódolást - azaz hitelességi hibát - azonban gyakorlatilag nem találtak $(0,3 \%)$.

\section{Megbeszélés}

Az OEP-nek adott jelentések elemzésével az agyinfarktus néhány jellegzetességét vizsgáltuk annak megállapítására, hogy a finanszírozási adatbázisok elemzése milyen mértékben alkalmas epidemiológiai jellegű kérdések megválaszolására. Megállapítottuk, hogy az ellátási területek változásának hatása jól követhető; vizsgálható, hogy az agyinfarktus indokolta a kórházi felvételt vagy csak kísérő betegségként szerepelt, illetve elemezhető az egyes kórházi struktúrán belül a szakterületek megoszlása az adott kórképek ellátásában.

Epidemiológiai elemzések során nehézséget jelenthet az, hogy a BNO-kódolás nem tesz különbséget a stroke akut (például 24 órán vagy akár 1 héten belüli tünetkezdet) vagy késői fázisa között sem. Mindössze arról nyilatkozhatunk, hogy a beteget aktív ágyon vagy krónikus ágyon kezelték. Megtévesztő lehet az aktíp ágy és az akut esemény közötti megkülönböztetés hiánya. Az OEP-jelentések a kezelés lezárásának adatait tartalmazzák, és nem jelzik a betegség súlyosságát és stádiumait.

Ma már az informatikai jelentések lehetővé teszik nemcsak az egyszerü forgalmi adatok alapján történő adatfeldolgozást, hanem akár orvosra, betegségre, esetleg a betegre történő adatelemzést is. Az egy esetre vonatkozó adatok összekapcsolása (úgynevezett „record linkage") napjainkban az epidemiológia elfogadott és gyakran alkalmazott módszere [8].

A finanszírozási célból készült adatbázisok epidemiológiai kutatás céljára történő hasznosíthatóságát régóta vizsgálják, és megbízhatónak tartják például a syncope [9] és az epilepszia [10] vonatkozásában. Cerebrovascularis betegségeket illetően a nemzetközi kódolási szokások Európában eltérőek, függenek az egyes országokra specifikus finanszírozási súlyszámoktól [11]. Egy dán vizsgálatban akut stroke diagnózisok vonatkozásában a nemzeti stroke-regiszter ugyan szenzitívebb volt, mint a kórházi adminisztratív adatbázis, de a két adatforrás po- zitív előrejelző értéke nem különbözött [12]. A BNO 9. verziójának megbízhatóságát több vizsgálatban elemezték és régiónként eltérő következtetésekre jutottak [13, 14, 15], a módszert általában alacsony szenzitivitásúnak, de magas specificitásúnak találták nagy pozitív prediktív értékkel [16, 17, 18]. Hasonló következtetésre jutottak a thrombolysissel kezelt esetek tekintetében is: az adminisztratív adatbázisok körülbelül 20\%-kal alulbecslik a thrombolysissel kezelt stroke-esetek arányát [19].

A Betegségek Nemzetközi Osztályozása (BNO) 9. és 10. verzióját összehasonlítva mindkét kódolás alkalmas a stroke és kockázati tényezőik azonosítására [20], és a komorbiditások figyelembevételével mindkét kódolást alkalmasnak találták a kórházi halálozás előrejelzésére is [21]. A cerebrovascularis betegségeket illetően nem volt szignifikáns különbség a BNO-9 és a BNO-10 kódolás között [22], azonban a BNO-10 kódrendszert pontosabb adatszolgáltatásra alkalmasabbnak tartják [23]. Az alkalmazhatóság feltétele a kódolás minőségének javulása és validálási vizsgálatok végzése [24]. Az elemzések pontosságának további feltétele a megfelelő informatikai módszerek alkalmazása [17, 25]. Az ilyen elemzéseknél figyelembe kell venni azt is, hogy a HBCs-rendszer bevezetése is megváltoztathatja a kódolási szokásokat [26].

A finanszírozási adatbázisok használata nagyon precíz diagnózisok szakmai elemzésére nem alkalmas, hiszen az adatrészletességet nem a szakmai kutatások, hanem a statisztikai és finanszírozási követelményeknek megfelelően alakították ki. Éppen ezért, nem az öt számjegyü, túl részletes, hanem a három számjegyü $\mathrm{BNO}$-10-kódok alkalmazását javasoljuk az epidemiológiai elemzésekhez. Az adminisztratív adatbázisokat alkalmasnak tartják populációalapú stroke epidemiológiai vizsgálatokra, ha megfelelő epidemiológiai és informatikai módszereket és definíciókat alkalmaznak [27, 28, 29].

Mivel a stroke-esetek többsége az idős korosztályt érinti, esetükben a stroke nem feltétlenül az ápolást indokoló diagnózisként szerepel a jelentésekben, ezért nagyobb hatékonysággal, nagyobb szenzitivitással találhatók meg az agyinfarktusesetek, ha nemcsak az ápolást indokló fó diagnózisként, hanem a kísérő betegségként kódolt eseteket is figyelembe vesszük [30, 31]. Ezzel szemben viszont a diagnózis pontosabb (a specificitás jobb, a szenzitivitás viszont kisebb), ha kizárólag az ápolást indokoló fó diagnózist vesszük figyelembe. A finanszírozási előny céljából történő hibás típuskódolás az ápolást indokoló fó diagnózist csak elhanyagolható mértékben érinti. A kódolási hiba fóként a szövődményekre és a kísérő betegségekre vonatkozik, amelyeknek HBCsbesorolási következményei vannak, és finanszírozási előnnyel járnak [32]. Ismert a finanszírozási „betegségek" megjelenése $[33,34]$, és ezek kiszưrési metodikái is [35].

Elemzéseink és mások vizsgálatai alapján kimondható, hogy a finanszírozási célból létrehozott adatbázisok a kapacitásadatok és a forgalmi adatok vizsgálatán túl megfelelő informatikai módszerek és szürőfeltételek mellett 
alkalmazhatók epidemiológiai vizsgálatokra is [36], és az ilyen adatbázisok pontossága elégséges kutatási és döntéshozási célokra [37]. Az adminisztratív adatbázisok az egyes kórházi osztályok szintjén is alkalmasak az ellátásszervezési változások következményeinek vizsgálatára. Megállapítható és elemezhető, hogy egy adott kórkép ellátásában a kórházak szintjén hogyan oszlik meg az egyes szakmák részvétele. Vizsgálható, hogy egy adott osztály vonatkozásában az egyes kórképek ellátása milyen arányban történik. Megállapítható, hogy az egyes kórképeket milyen szakterületek látják el. Vizsgálható, hogy az adott kórképeket milyen arányban kezelik aktív és krónikus ágyakon, és az is, hogy milyen módon hat a környezet és az életmód a betegség életkori megjelenésére. Az agyinfarktus vonatkozásában az adatbázis jelenleg nem ad arra direkt lehetőséget, hogy elkülönítsük a betegség akut, szubakut vagy krónikus fázisát. Ehhez jelenleg kiegészítő adatelemzések adnak becslési lehetőséget. Az optimális megoldás a kötelező adatszolgáltatás lenne a stroke vonatkozásában is - erre a kórházi adatlap utolsó sora elvi lehetőséget is ad. Az OEP-számra benyújtott adatbejelentő lapok módosításával kis idő- és energiabefektetéssel lehetségessé válhat klinikai és ellátásszervezési szempontból is jelentős adatok begyújtése és elemzése - a Nemzeti Stroke Regiszter megvalósítása.

Anyagi támogatás: A közlemény a KTIANAP-13-1-2013-0001 pályázati támogatás segítségével készült.

Szerzői munkamegosztás: A. A.: Az adatok válogatása, a hipotézis megfogalmazása, adatelemzés, a kézirat szerkesztése. O. F.: A hipotézis kidolgozása, adatelemzés, szempontrendszer, a kézirat verzióinak kritikus átolvasása. B. D.: Adatelemzés, a hipotézis megfogalmazása, a kézirat szerkesztése. A cikk végleges változatát mindhárom szerző elolvasta és jóváhagyta.

Érdekeltségek: A szerzőknek nincsenek érdekeltségeik.

\section{Köszönetnyilvánítás}

A szerzők köszönik az élelmezésben résztvevő osztályok munkatársainak együttmúködését.

\section{Irodalom}

[1] Bereczki, D., Ajtay, A.: Neurology 2009: a survey of the neurological capacities, their utilization and neurologists based on the 2009 reports of the institutions in Hungary. [Neurológia 2009: helyzetfelmérés a magyarországi neurológiai kapacitásokról, azok kihasználtságáról és a szakorvosokról a 2009-es intézményi jelentések alapján.] Ideggyogy. Sz., 201 1, 64(5-6), 173-185. [Hungarian]

[2] Bereczki, D., Csiba, L., Komoly, S., et al.: The career model of neurology in Hungary. a proposal for the solution until 2020. [A neurológia magyarországi (élet)pályamodellje - megoldási javas- lat 2020-ig.] Ideggyogy. Sz., 2011, 64(11-12), 377-384. [Hungarian]

[3] Stausberg, J., Lehmann, N., Kaczmarek, D., et al.: Reliability of diagnoses coding with ICD-10. Int. J. Med. Inform., 2008, $77(1), 50-57$.

[4] St. Germaine-Smith, C., Metcalfe, A., Pringsheim, T., et al.: Recommendations for optimal ICD codes to study neurologic conditions: a systematic review. Neurology, 2012, 79(10), 10491055.

[5] Casas, M.: Issues for comparability of DRG statistics in Europe. Results from EURODRG. Health Policy, 1991, 17(2), 121-132.

[6] Healthcare Strategic Research Institute: Itemized Healthcare Database. [Egészségügyi Stratégiai Kutató Intézet: Tételes Egészségügyi Adattár.] www.eski.hu. [Hungarian]

[7] Ajtay, A., Bartha, G.: Analysis and national monitoring of hospital treatment of cerebrovascular patients in the 2 nd quarter of 2005. [Cerebrovascularis (agy-ér rendszeri) megbetegedések kórházi ellátásának elemzése és 2005. II. negyedévi országos ellenőrzése.] Országos Egészségbiztosítási Pénztár Elemzési és Szakmai Ellenőrzési Főosztály, 2005/29. [Hungarian]

[8] Boyd, J. H., Randall, S. M., Ferrante, A. M., et al.: Technical challenges of providing record linkage services for research. BMC Med. Inform. Decis. Mak., 2014, 14, 23. doi: 10.1186/14726947-14-23.

[9] Ruwald, M. H., Hansen, M. L., Lamberts, M., et al.: Accuracy of the ICD-10 discharge diagnosis for syncope. Europace, 2013, 15(4), 595-600.

[10] Jetté, N., Reid, A. Y., Quan, H., et al.: How accurate is ICD coding for epilepsy? Epilepsia, 2010, 51(1), 62-69.

[11] Peltola, M., Quentin, W.: Diagnosis-related groups for stroke in Europe: patient classification and hospital reimbursement in 11 countries. Cerebrovasc. Dis., 2013, 35(2), 113-123.

[12] Wildenschild, C., Mehnert, F., Thomsen, R. W., et al.: Registration of acute stroke: validity in the Danish Stroke Registry and the Danish National Registry of Patients. Clin. Epidemiol., 2014, 6, 27-36.

[13] Benesch, C., Witter, D. M. Jr., Wilder, A. L., et al.: Inaccuracy of the International Classification of Diseases (ICD-9-CM) in identifying the diagnosis of ischemic cerebrovascular disease. Neurology, 1997, 49(3), 660-664.

[14] Jones, S. A., Gottesman, R. F., Shahar, E., et al.: Validity of hospital discharge diagnosis codes for stroke: the Atherosclerosis Risk in Communities Study. Stroke, 2014, 45(11), 3219-3225.

[15] Ellekjaer, H., Holmen, J., Krüger, O., et al.: Identification of incident stroke in Norway: hospital discharge data compared with a population-based stroke register. Stroke, 1999, 30(1), 56-60.

[16] Roumie, C. L., Mitchel, E., Gideon, P. S., et al.: Validation of ICD9 codes with a high positive predictive value for incident strokes resulting in hospitalization using Medicaid health data. Pharmacoepidemiol. Drug Saf., 2008, 17(1), 20-26.

[17] Kumamaru, H., Judd, S. E., Curtis, J. R., et al.: Validity of claims-based stroke algorithms in contemporary Medicare data: reasons for geographic and racial differences in stroke (REGARDS) study linked with medicare claims. Circ. Cardiovasc. Qual. Outcomes, 2014, 7(4), 611-619.

[18] Haesebaert, J., Termoz, A., Polazzi, S., et al.: Can hospital discharge databases be used to follow ischemic stroke incidence? Stroke, 2013, 44(7), 1770-1774.

[19] Palazzo, P., Alexandrov, A. V., Alexandrov, A. W.: Do billing codes accurately capture intravenous tissue plasminogen activator treatment rates? Justified concern for clinical performance measures based on billing code assignment. J. Stroke Cerebrovasc. Dis., 2015, 24(2), 327-329.

[20] Kokotailo, R. A., Hill, M. D.: Coding of stroke and stroke risk factors using International Classification of Diseases, Revisions 9 and 10. Stroke, 2005, 36(8), 1776-1781. 
[21] Zhu, H., Hill, M. D.: Stroke: the Elixhauser Index for comorbidity adjustment of in-hospital case fatality. Neurology, 2008, $71(4), 283-287$.

[22] Quan, H., Li, B., Saunders, L. D., et al.: Assessing validity of ICD-9-CM and ICD-10 administrative data in recording clinical conditions in a unique dually coded database. Health Serv. Res., 2008, 43(4), 1424-1441.

[23] Kirkman, M. A., Albert, A. F.: Accuracy of hospital discharge coding is important in assessing trends in stroke rates. Swiss Med. Wkly, 2009, 139(31-32), 463-464.

[24] Palmer, W. L., Bottle, A., Davie, C., et al.: Meeting the ambition of measuring the quality of hospitals' stroke care using routinely collected administrative data: a feasibility study. Int. J. Qual. Health Care, 2013, 25(4), 429-436.

[25] Flynn, R. W., MacDonald, T. M., Murray, G. D., et al.: The Tayside Stroke Cohort: exploiting advanced regional medical informatics to create a region-wide database for studying the pharmacoepidemiology of stroke. Pharmacoepidemiol. Drug Saf., 2010, 19(7), 737-744.

[26] Derby, C. A., Lapane, K. L., Feldman, H. A., et al.: Possible effect of DRGs on the classification of stroke: implications for epidemiological surveillance. Stroke, 2001, 32(7), 1487-1491.

[27] Gillum, R. F.: New considerations in analyzing stroke and heart disease mortality trends: the Year 2000 Age Standard and the International Statistical Classification of Diseases and Related Health Problems, 10th Revision. Stroke, 2002, 33(6), 17171721.

[28] Benchimol, E. I., Manuel, D. G., To, T., et al.: Development and use of reporting guidelines for assessing the quality of validation studies of health administrative data. J Clin. Epidemiol., 2011, $64(8), 821-829$.
[29] Lakshminarayan, K., Larson, J. C., Virnig, B., et al.: Comparison of Medicare claims versus physician adjudication for identifying stroke outcomes in the Women's Health Initiative. Stroke, 2014, 45(3), 815-821.

[30] Goldstein, L. B.: Accuracy of ICD-9-CM coding for the identification of patients with acute ischemic stroke: effect of modifier codes. Stroke, 1998, 29(8), 1602-1604.

[31] Tirschwell, D. L., Longstreth, W. T. Jr.: Validating administrative data in stroke research. Stroke, 2002, 33(10), 2465-2470.

[32] Hsia, D. C., Krushat, W. M., Fagan, A. B., et al.: Accuracy of diagnostic coding for Medicare patients under the prospectivepayment system. N. Engl. J. Med., 1988, 318(6), 352-355.

[33] Simborg, D. W.: DRG creep: a new hospital-acquired disease. N. Engl. J. Med. 1981, 304(26), 1602-1604

[34] Helms, C. M.: A pseudo-epidemic of septicemia among Medicare patients in Iowa. Am. J. Public Health, 1987, 77(10), 13311332.

[35] Kusserow, R. P., Steeley, B. L.: DRG "creep". Pitfalls and sanctions to avoid. Consultant, 1989, 29(3), 93-95, 98-99.

[36] Jiang, G., Pathak, J., Chute, C. G.: Formalizing ICD coding rules using Formal Concept Analysis. J. Biomed. Inform., 2009, 42(3), 504-517.

[37] Burns, E. M., Rigby, E., Mamidanna, R., et al.: Systematic review of discharge coding accuracy. J. Public Health (Oxf.), 2012, 34(1), 138-148.

(Bereczki Dániel dr., Budapest, Balassa u. 6., 1083 e-mail: bereczki.daniel@med.semmelweis-univ.hu)

\section{A rendezvények és kongresszusok híranyagának leadása}

a lap megjelenése előtt legalább 40 nappal lehetséges, a 6 hetes nyomdai átfutás miatt. Kérjük megrendelőink szíves megértését.

A híranyagokat a következő címre kérjük:

Orvosi Hetilap titkársága: Budai.Edit@akkrt.hu

Akadémiai Kiadó Zrt. 